\title{
Assessment of Individual and Organizational Characteristics on Job Satisfaction Level: An Empirical Analysis
}

\author{
Orhan Kocak ${ }^{1}$, Serdar Aydin ${ }^{2 *}$, Mustafa Z Younis ${ }^{3}$, Nurefsan Tomac ${ }^{4}$
}

\author{
${ }^{1}$ Istanbul University Cerrahpasa, Faculty of Health Science, Istanbul, TURKEY \\ ${ }^{2}$ Southern Illinois University - Carbondale, School of Health Sciences, Carbondale, Illinois, USA \\ ${ }^{3}$ Jackson State University, Jackson, MS, USA \\ ${ }^{4}$ Uskudar University Department of Social Work, Istanbul, TURKEY \\ *Corresponding Author: serdar.aydin@siu.edu
}

Citation: Kocak, O., Aydin, S., Younis, M. Z. and Tomac, N. (2020). Assessment of Individual and Organizational Characteristics on Job Satisfaction Level: An Empirical Analysis. European Journal of Environment and Public Health, 4(2), em0052. https://doi.org/10.29333/ejeph/8370

\section{ARTICLE INFO}

Received: 26 Apr. 2020

Accepted: 16 Jun. 2020

\begin{abstract}
For most people, working is essential in order to earn the economic income that is required to sustain one's life. Within this framework, the research has been conducted on the meaning of work, its importance, and its benefits for the worker. An important part of existing research are investigations into "job satisfaction," which expresses whether people are happy and fulfilled in their work.

This research adds to that literature as the authors have researched job satisfaction levels of working individuals to discover important variables that affect job satisfaction. The research was conducted in 2018 with 217 professional staff working in the Anatolian part of Istanbul. In this research, both a "Personal Information Form" and "Job Satisfaction Scale" were used.
\end{abstract}

Keywords: satisfaction, job satisfaction, organizational characteristics, job enrichment

\section{INTRODUCTION}

With today's competitiveness and drive for performance, the capability of organizations to survive and compete depends on their ability to use their resources in the most effective and efficient way. The most important asset of an organization is its employees, and their performance and productivity are some of the most important factors affecting the success of the organization. The ability of employees to demonstrate high performance and to work effectively and efficiently depends in large part on their ability to achieve an adequate level of job satisfaction (Aksit, 2010).

Employees' abilities to manage time, establish good communications and social relations, earn recognize for their talents, and develop their skills are essential components in fostering an organization environment that is healthy, happy, efficient and productive. It is, therefore, crucial to know the job satisfaction levels of the employees and to know the positive or negative factors affecting these levels.

Although some outcomes are generally easy and unmistakable to measure, mostly objective instruments such as death and income, others can be difficult to measure. Satisfaction is one of them being difficult to measure and can be measured indirectly by asking users to rate the quality of services that they have received or experienced (Aydin, 2019).

Working is an indispensable part of life. Employees spend a significant part of their days at work for an average of 25-30 years of their lives. For this reason, job satisfaction of the employees in their work is extremely important in terms of psychological and physical health. The effort to increase job satisfaction by developing and enriching the knowledge, productivity and communication skills can make the private and working life of workers more meaningful and productive and make them feel they are contributing more to the society.

Job satisfaction is defined as the conditions created by the psychological, physiological and environmental factors that make it possible for individuals to say that they are satisfied with their jobs. Vroom (1964) defines job satisfaction as an emotional orientation of the individuals for their roles in their work. According to Locke's (1976) accepted definition of job satisfaction, it is a positive feeling as the result of the assessment of a person towards his/her job or work experience.

Locke identifies the components of job satisfaction as the job itself, wages, promotion, working conditions, benefits provided by the job, the values possessed by the employee, and the relations that are established between the employee and the manager (Aslan, 2006). Robbins (2000) defines job satisfaction as the general attitude of a worker towards his/her 
job. According to this definition, people with high job satisfaction develop positive attitudes towards their jobs and those with low job satisfaction develop negative attitudes towards their jobs.

In the definition of job satisfaction, three essential aspects are prevalent: a) Job satisfaction refers to the employee's subjective and personal feelings about work. b) Job satisfaction cannot be observed in general but can be understood from the behavior of the person. c) Job satisfaction is experienced when employees achieve the awards they deserve or believes they deserve, or when they gain awards or promotions beyond their expectations (Solmus, 2004).

Factors such as educational background, work experience, and social environment of the person are shaping evaluations of work and work conditions and are effective in the development of attitudes towards working. For this reason, it is necessary to examine factors that have an impact on job satisfaction or job dissatisfaction (Eginli, 2009). Factors in this context can be classified as individual and organizational factors.

Individual factors that have a significant effect on the formation of job satisfaction relate to the experiences that one acquires throughout his/her lifetime, along with the person's various innate characteristics. In this context, factors such as age, gender, and education of a person directly affect the perception of the person concerning the current conditions in the work (Atakli et al., 2004). Factors affecting job satisfaction can be classified by gender, age, education level, motivation, performance.

Organizational factors, on the other hand, that are perceived as tasks and performed in a specific organizational setting at a specific time, can also be defined as a contribution or value provided to the workplace by the employee. These variables can be considered from the level of knowledge and skills required for the job to the socio-economic contribution that the job provides to the employee (Aksit, 2010). Organizational factors affecting job satisfaction can be classified as wages, opportunities for promotion, rewards, duration of work, work environment, job and social security.

In his comprehensive view of job satisfaction, Locke (1978) described factors positively affecting job satisfaction, including the following: a) a mentally challenging job that a person can successfully accomplish; b) a job that falls into the area of personal interest; c) award is indented to increase performance by providing fair and informative content is satisfactory. d) employers who accommodate workers' physical needs; e) a job that facilitates award-winning environment is satisfying g) working with colleagues who have the same perspective $h$ ) companies that have the administrative structure that is regulated to help employees winning to achieve their goals within the work environment.

Dissatisfaction is higher in companies where there are contradictory or vague job description and where work is exhausting. In research by Clark and Oswald (1995) the relationship between job satisfaction and wages indicated a decrease in the level of job satisfaction of employees with low wages (Groot \& Van Den Brink, 1999).

For most of the employees, there is no strong influence of additional resources in the work for job satisfaction (Aslan,
2006). Glenn et al. (1977) found that older workers had higher levels of job satisfaction than younger workers, according to the research they conducted on the relationship between age and job satisfaction. High self-esteem can also positively affect job satisfaction (Locke, 1978).

As a result of research that examines the differences between job satisfaction of women and men, Clark (1993) stated that the job satisfaction of women was found higher than men (Groot \& Van Den Brink, 1999). In the study that Oshagbemi (2003) conducted to examine the relationship between job satisfaction and personal characteristics of academic staff, he found that job satisfaction of academic staff is related to the duration of service and the high level of education.

This study was conducted in order to determine the job satisfaction levels of employees. The following questions were employed in this research.

- How are job satisfaction levels of employees?

- What are the factors that affect job satisfaction level?

\section{METHODOLOGY}

The study group of this study consisted of 217 workers living in Istanbul: 111 of them were women (51.2\%) and 106 of them were men $(48.8 \%)$ in the age range of $15-64$ years. The demographic characteristics of the employees are presented in Table 1.

A total of 217 adult employees with various demographic characteristics participated voluntarily in the research. $51.2 \%$ of the employees are women and $48.8 \%$ are men and the largest age group is those who are in the $25-34$ ages (53.0\%). The vast majority of employees have an education level of undergraduate or graduate $(88.0 \%)$ and $52.1 \%$ of them are married. When the total study period of the research participants is examined, it is seen that the largest group is employees who have worked for 5-10 years (30.4\%) and the smallest group is employees who have been working less than 1 year (7.4\%). $74.2 \%$ of employees stated that they had job changes between zero and 3 times, $22.1 \%$ of them had changed jobs 4-7 times, and 3.7\% of them had changed 8-10 times. The vast majority of employees have been working in the current workplace for less than 1 year (30.4\%) and $1-5$ years (35.5\%). $25.8 \%$ of participants work in the public sector and $74.2 \%$ of them in the private sector. Finally, the participants in the research reported that they have the following monthly income: \%35 of them have 1,500.00-3,000.00 TL, 35\% of them have $3,001.00-4,500.00 \mathrm{TL}, 15.7 \%$ of them have $4,501.00$ $6,000.00 \mathrm{TL}$, and the remaining $14.3 \%$ have higher than 6,000.00 TL.

\section{Data Collection Methods}

In this study, a personal information form and a measurement tool were used as the data collection methods.

\section{Personal information form}

A form consisting of a total of nine questions, was used to find out the demographic (personal) characteristics of the employees who participated in the study. In this form nine questions were asked, including gender, age, educational 
Table 1. Frequency and percentage distributions of employees' demographics

\begin{tabular}{|c|c|c|c|}
\hline Variable & Group & $\mathbf{f}$ & $\%$ \\
\hline \multirow{2}{*}{ Gender } & Woman & 111 & 51.2 \\
\hline & Man & 106 & 48.8 \\
\hline \multirow{5}{*}{ Age } & $15-24$ & 21 & 9.7 \\
\hline & $25-34$ & 115 & 53.0 \\
\hline & $35-44$ & 54 & 24.9 \\
\hline & $45-54$ & 17 & 7.8 \\
\hline & $55-64$ & 10 & 4.6 \\
\hline \multirow{3}{*}{ Education Level } & Elementary-Middle School & 4 & 1.8 \\
\hline & High School & 22 & 10.1 \\
\hline & $\begin{array}{l}\text { Undergraduate and } \\
\text { Graduate Programs }\end{array}$ & 191 & 88.0 \\
\hline \multirow{2}{*}{ Marital Status } & Married & 113 & 52.1 \\
\hline & Single & 104 & 47.9 \\
\hline \multirow{5}{*}{ Working experience } & Less than 1 year & 16 & 7.4 \\
\hline & 1-5 Years & 57 & 26.3 \\
\hline & $5-10$ years & 66 & 30.4 \\
\hline & $10-15$ years & 35 & 16.1 \\
\hline & 15 years and more & 43 & 19.8 \\
\hline \multirow{3}{*}{$\begin{array}{c}\text { The number of Times } \\
\text { Changed Jobs over the } \\
\text { Years. }\end{array}$} & $0-3$ times & 161 & 74.2 \\
\hline & 4-7 times & 48 & 22.1 \\
\hline & 8-10 times & 8 & 3.7 \\
\hline \multirow{5}{*}{$\begin{array}{l}\text { The duration of } \\
\text { employment } \\
\text { with the current Job }\end{array}$} & Less than 1 year & 66 & 30.4 \\
\hline & $1-5$ years & 77 & 35.5 \\
\hline & $5-10$ years & 45 & 20,7 \\
\hline & $10-15$ years & 15 & 6,9 \\
\hline & 15 years and more & 14 & 6,5 \\
\hline \multirow{2}{*}{ Job Sector } & Public Services & 56 & 25,8 \\
\hline & Private Companies & 161 & 74.2 \\
\hline \multirow{4}{*}{$\begin{array}{c}\text { Income from Current } \\
\text { Job }\end{array}$} & $1500-3000$ & 76 & 35.0 \\
\hline & $3001-4500$ & 76 & 35.0 \\
\hline & $4501-6000$ & 34 & 15.7 \\
\hline & 6000 and more & 31 & 14.3 \\
\hline
\end{tabular}

status, marital status, work experience, number of jobs changed during their work history, the duration of employment with the current job, job sector, and income from the current job (Table 1).

\section{Occupational satisfaction scale}

The Occupational Satisfaction Scale developed by Kuzgun, Sevim and Hamamc1 (2005) was utilized to find out the level of job satisfaction depending on the current jobs of the employees who participated in the research. As a result of the factor analysis made by the researchers, the 5-point Likert type scale, between 'never' (1) and 'always' (5), consists of a total of 20 questions, six of which are inverted (negative), is identified as having a two dimensional structure. The first dimension of the scale (Suitability to Qualities) describes $36.4 \%$ of the $\% 48,6$ total variance and $12.2 \%$ of the variance describes the second (Desire to Self-Improvement) dimension of the variance. Individuals can gain total score ranges from 20 to 100, with high scores representing high levels of job satisfaction (Kuzgun et al., 2005).

As a result of the reliability-validity analysis of the scale, the researchers calculated the general reliability coefficient (Cronbach's Alpha) as $0.90 ; 0.91$ for the first subscale of scale and 0.75 for the second dimension. The appropriateness of the Occupational Satisfaction Scale for this study was investigated by using an Alpha model with an item analysis based on their reliability. The reliability of the scale based on the alpha $(\alpha)$ coefficient is evaluated as follows.

The scale / dimension is not reliable if $0.00 \leqslant \alpha<0.40$,

If $0.40 \leqslant \alpha<0.60$, then scale / dimension reliability is low,

If $0.60 \leqslant \alpha<0.80$ then the scale / size is quite reliable

If $0.80 \leqslant \alpha<1.00$, the scale / dimension is highly reliable (Kalayci, 2006; Karagoz, 2016).

Table 2 presents the result of the reliability analysis for the Occupational Satisfaction Scale.

Table 2. The result of the reliability analysis of Occupational Satisfaction Scale

\begin{tabular}{|c|c|c|}
\hline Item & $\begin{array}{l}\text { Item-Total } \\
\text { Correlation }\end{array}$ & $\begin{array}{c}\text { Cronbach's Alpha When } \\
\text { the item is cleared }\end{array}$ \\
\hline 01. Would you like to enter the same profession if you come to the world once again? & 0.731 & 0.904 \\
\hline 02. Do you find your job important and meaningful? & 0.708 & 0.905 \\
\hline 03. Would you recommend your profession to others? & 0.715 & 0.905 \\
\hline 04. Would you ever say, I wish I would be someone who does another job? & 0.606 & 0.908 \\
\hline 05. Do you think your profession allows you to develop? & 0.639 & 0.907 \\
\hline 06. Are you coming to your workplace enthusiastically? & 0.733 & 0.905 \\
\hline 07. Would you try to learn something new about your job? & 0.561 & 0.910 \\
\hline 08. Are you doing a job that is appropriate for your educational background in your workplace? & 0.550 & 0.909 \\
\hline 09. Do you feel unhappy and bored at the end of the business day? & 0.471 & 0.911 \\
\hline 10. At a moment when you have the chance, would you think about changing your job? & 0.613 & 0.908 \\
\hline 11. Would you think of retiring early and focus mostly on your own personal life? & 0.512 & 0.912 \\
\hline 12. When you meet your colleagues, do you ask how they do their work? & 0.307 & 0.912 \\
\hline 13. Would you participate in seminars, congresses to increase your professional knowledge? & 0.422 & 0.912 \\
\hline 14. Do some obstacles in your workplace prevent your desire to work? & 0.398 & 0.912 \\
\hline 15. Do you think your job suits your skills? & 0.646 & 0.907 \\
\hline 16. Would you follow the publications on your profession? & 0.568 & 0.909 \\
\hline 17. Are you struggling with the obstacles you face while working in your profession? & 0.317 & 0.910 \\
\hline 18. Do you think your work fits your personal interests? & 0.754 & 0.904 \\
\hline 19. Has there been a moment where you think that "I should change my profession"? & 0.683 & 0.906 \\
\hline 20. Do you attempt to increase your knowledge in your profession? & 0.438 & 0.912 \\
\hline The reliability coefficient of Occupational Satisfaction Scale $(\alpha)$ & & 0.913 \\
\hline
\end{tabular}


Table 3. Descriptive statistics on job satisfaction levels of employees $(\mathrm{N}=217)$

\begin{tabular}{cccccc}
\hline Scale & Possible Point Score & Lowest Score & Highest Score & $\overline{\boldsymbol{X}}$ & Ss \\
\hline Job Satisfaction & $20.00-100.00$ & 28.00 & 99.00 & 69.80 & 15.11 \\
\hline
\end{tabular}

Table 4. T-test to find out whether employees' job satisfaction levels (scores) differ by gender (N=217)

\begin{tabular}{|c|c|c|c|c|c|c|c|}
\hline \multirow{2}{*}{ Score } & \multirow{2}{*}{ Gender } & \multicolumn{3}{|c|}{ Descriptive Statistic } & \multicolumn{3}{|c|}{ t-test } \\
\hline & & $\mathbf{n}$ & $\bar{X}$ & SS & $\mathbf{t}$ & sd & $\mathbf{p}$ \\
\hline \multirow{2}{*}{ Job Satisfaction } & Woman & 111 & 72.81 & 14.30 & 3.06 & 215 & $0.002 * * *$ \\
\hline & Man & 106 & 66.64 & 15.37 & & & \\
\hline
\end{tabular}

Table 5. Kruskal-Wallis test to find out whether the level of job satisfaction (scores) of employees varies according to age (N=217)

\begin{tabular}{|c|c|c|c|c|c|c|c|}
\hline \multirow{2}{*}{ Score } & \multirow{2}{*}{ Age } & \multicolumn{2}{|r|}{ Descriptive Ist. } & \multicolumn{3}{|c|}{ Kruskal-Wallis } & \multirow[b]{2}{*}{ M-W } \\
\hline & & $\mathbf{n}$ & Average in Sequence. & $\mathrm{X}^{2}$ & sd & $\mathbf{p}$ & \\
\hline \multirow{5}{*}{ Job Satisfaction } & $15-24(1)$ & 21 & 97.00 & 18.30 & 4 & $0.001^{* * *}$ & 1.2 ile 4 \\
\hline & $25-34(2)$ & 115 & 98.87 & & & & \\
\hline & $35-44(3)$ & 54 & 113.30 & & & & \\
\hline & $45-54(4)$ & 17 & 162.59 & & & & \\
\hline & $55-64(5)$ & 10 & 136.35 & & & & \\
\hline
\end{tabular}

The general reliability coefficient of the scale (Cronbach's Alpha) was found to be $\alpha=0.913$. This rate indicates that the level of reliability among items of scale is very high There is also a sufficient relationship between the items of the scale and overall scale (item-total correlation between .307 and 0.754). After the item analysis for the Occupational Satisfaction Scale, the level of reliability was found sufficient for this research.

\section{Data Analysis}

All of the data gathered through the "Personal Information Form " and " Occupational Satisfaction Scale" from those who participated in the study to investigate the job satisfaction levels according to the employees' existing jobs and the data were analyzed by the SPSS 23.0 for Windows statistical package program. Before the data was analyzed, data obtained from the patients participating in the study are within the limits set by the survey and had any mistakes and deficiencies. Then, based on the applicability to the purpose of the study and the research questions, the normal distributions of the data groups were examined by looking at KolmogorovSmirnov (K-S) test results and the kurtosis-skewness values for the selection of the statistical analyzes.

For the research questions of the study, independent groups of parametric tests were investigated by t-test to find out whether there was any difference between job satisfaction levels based on the gender, marital status and working sector of the employees. One-way analysis of variance (ANOVA) of parametric tests was conducted to investigate whether there was a meaningful difference between the job satisfaction of the workers based on their current job. The non-parametric Kruskal-Wallis test was used to determine whether there was a significant difference between the job satisfaction levels according to the age, education status, working experience, number of jobs changed and the duration of employment with the current job. The significance level was accepted as .05 in all statistical calculations.

\section{FINDINGS AND DISCUSSIONS}

In this sub-section of the study, the level of job satisfaction of the employees was examined first in general and then through differentiated analysis based on demographic characteristics of the employees.

One-dimensional Occupational Satisfaction Scale with 20 items as the Likert type with 5 is evaluated between 'Never' (1) and 'Always' (5) by the individuals participating in the study. The total score can be taken from the scale ranges from 20 to 100 , and the high total score shows high job satisfaction. The lowest job satisfaction total score was found to be 28.00 and the highest job satisfaction was 99.00, and the average job satisfaction total score $\bar{X}$ was calculated as Job Satisfaction = $69.80 \pm 15.11$. This value indicates that the level of job satisfaction of the participants is not low but not too high.

The following is an analysis of whether the level of job satisfaction varies according to the demographic characteristics of the employees.

It was found that there is a significant difference between male and female workers' job satisfaction levels and this difference is found to be in favor of female employees (Table 4). When the average scores of the groups are examined, it is seen that female employees' job satisfaction levels are higher than male employees.

It was found that the level of job satisfaction of the employees participating in the research showed a significant difference according to the age variable (Table 5). The level of job satisfaction of workers in the 15-24 to 25-34 age group is significantly lower than that of the 45-54 age group.

According to the non-parametric Kruskal-Wallis $\mathrm{H}$ test that is used to find out whether job satisfaction levels (scores) show a significant difference based on educational level, it was found that there was no significant difference between the levels of job satisfaction based on educational attainment for the employees participating in the survey ( $p>.05$ ) (Table 6). 
Table 6. Kruskal-Wallis test to find out whether the level of job satisfaction (scores) of employees varies according to educational level $(\mathrm{N}=217)$

\begin{tabular}{|c|c|c|c|c|c|c|c|}
\hline \multirow{2}{*}{ Score } & \multirow{2}{*}{ Educational Level } & \multicolumn{2}{|c|}{ Descriptive Statistic } & \multicolumn{3}{|c|}{ Kruskal-Wallis } & \multirow{2}{*}{ M-W } \\
\hline & & $\mathbf{n}$ & Average in Sequence. & $\mathrm{X}^{2}$ & sd & p & \\
\hline \multirow{3}{*}{ Job Satisfaction } & Elementary-Middle School & 4 & 66.63 & 3.91 & 2 & 0.141 & - \\
\hline & High School & 22 & 91.64 & & & & \\
\hline & Undergraduate and Graduate & 191 & 111.89 & & & & \\
\hline
\end{tabular}

Table 7. Kruskal-Wallis test to find out whether the level of job satisfaction (scores) of employees varies according to marital status $(\mathrm{N}=217)$

\begin{tabular}{|c|c|c|c|c|c|c|c|}
\hline \multirow{2}{*}{ Score } & \multirow{2}{*}{ Marital Status } & \multicolumn{3}{|c|}{ Descriptive Statistic } & \multicolumn{3}{|c|}{ t-test } \\
\hline & & $\mathbf{n}$ & $\overline{\bar{X}}$ & ss & $t$ & sd & $\mathbf{p}$ \\
\hline \multirow{2}{*}{ Job Satisfaction } & Married & 113 & 72.88 & 14.41 & 3.20 & 215 & $0.002^{* * * *}$ \\
\hline & Single & 104 & 66.44 & 15.21 & & & \\
\hline
\end{tabular}

Table 8. Kruskal-Wallis test to find out whether the level of job satisfaction (scores) of employees varies according to working experience $(\mathrm{N}=217)$

\begin{tabular}{|c|c|c|c|c|c|c|c|}
\hline \multirow{2}{*}{ Score } & \multirow{2}{*}{ Working years } & \multicolumn{2}{|c|}{ Descriptive Statistic } & \multicolumn{3}{|c|}{ Kruskal-Wallis } & \multirow{2}{*}{ M-W } \\
\hline & & $\mathbf{n}$ & Sequence Average. & $\mathrm{X}^{2}$ & sd & p & \\
\hline \multirow{5}{*}{ Job Satisfaction } & Less than one year (1) & 16 & 106.66 & 10.23 & 4 & $0.037^{*}$ & 2 ile 5 \\
\hline & $1-5$ years $(2)$ & 57 & 97.39 & & & & \\
\hline & $5-10$ years (3) & 66 & 103.14 & & & & \\
\hline & $10-15$ years $(4)$ & 35 & 107.49 & & & & \\
\hline & 15 years and more (5) & 43 & 135.49 & & & & \\
\hline
\end{tabular}

Table 9. Kruskal-Wallis test to find out whether the level of job satisfaction (scores) of employees varies according to the number of jobs changes over the years $(\mathrm{N}=217)$

\begin{tabular}{|c|c|c|c|c|c|c|c|}
\hline \multirow{2}{*}{ Score } & \multirow{2}{*}{ Number of Jobs Changed } & \multicolumn{2}{|c|}{ Descriptive Statistics } & \multicolumn{3}{|c|}{ Kruskal-Wallis } & \multirow{2}{*}{ M-W } \\
\hline & & $\mathbf{n}$ & Average in Sequence. & $\mathbf{X}^{2}$ & sd & $\mathbf{p}$ & \\
\hline \multirow{3}{*}{ Job Satisfaction } & $0-3$ times & 161 & 106.87 & 1.64 & 2 & 0.440 & - \\
\hline & 4-7 times & 48 & 118.42 & & & & \\
\hline & 8-10 times & 8 & 95.38 & & & & \\
\hline
\end{tabular}

Table 10. Kruskal-Wallis test to find out whether the level of job satisfaction (scores) of employees varies according to the duration of employment with the current Job $(\mathrm{N}=217)$

\begin{tabular}{|c|c|c|c|c|c|c|c|}
\hline \multirow{2}{*}{ Score } & \multirow{2}{*}{$\begin{array}{c}\text { Duration of Employment in } \\
\text { the Current Job }\end{array}$} & \multicolumn{2}{|c|}{ Descriptive Statistics } & \multicolumn{3}{|c|}{ Kruskal-Wallis } & \multirow{2}{*}{ M-W } \\
\hline & & $\mathbf{n}$ & Average in Sequence & $\mathrm{X}^{2}$ & sd & $\mathbf{p}$ & \\
\hline \multirow{5}{*}{ Job Satisfaction } & 1 year or less & 66 & 101.05 & 3.15 & 4 & 0.532 & - \\
\hline & $1-5$ years & 77 & 108.88 & & & & \\
\hline & $5-10$ years & 45 & 110.38 & & & & \\
\hline & $10-15$ years & 15 & 121.23 & & & & \\
\hline & 15 years or more & 14 & 129.57 & & & & \\
\hline
\end{tabular}

It was found that there was a significant difference between job satisfaction levels of married and single employees and this difference was found to be in favor of married employees (Table 7). When the average scores of the groups are examined, it is seen that the level of job satisfaction of married employees is higher than single employees.

It was found that the level of job satisfaction of the employees participating in the research showed a significant difference according to the variable of total working years (work life) (Table 8). The level of job satisfaction of employees with 1-5 years working experience is lower than employees who have 15 years or more years of working experience.

According to the non-parametric Kruskal-Wallis $\mathrm{H}$ test that is used to find out whether job satisfaction levels (scores) show a significant difference based on the number of job changes over the years, it was found that there was no significant difference between the job satisfaction levels based on the number of jobs held ( $p>.05$ ) (Table 9).

According to the non-parametric Kruskal-Wallis $\mathrm{H}$ test that is used to find out whether job satisfaction levels (scores) show a significant difference based on the duration of employment in the current job, it was found that there was no significant difference between the job satisfaction levels of the employees ( $p>$.05) (Table 10).

There was no significant difference between the job satisfaction levels of the employees according to the independent groups' t-test ( $p>.05$ ) (Table 11) that was employed to find out whether the employees' job satisfaction levels differed significantly according to the sectors they worked in. 
Table 11. Kruskal-Wallis test to find out whether the level of job satisfaction (scores) of employees varies according to the job sector $(\mathrm{N}=217)$

\begin{tabular}{|c|c|c|c|c|c|c|c|}
\hline \multirow{2}{*}{ Score } & \multirow{2}{*}{ Sector } & \multicolumn{3}{|c|}{ Descriptive Statistic } & \multicolumn{3}{|c|}{ t-test } \\
\hline & & $\mathbf{n}$ & $\bar{X}$ & ss & $\mathbf{t}$ & sd & $\mathbf{p}$ \\
\hline \multirow{2}{*}{ Job Satisfaction } & Public Sector & 56 & 71.48 & 14.67 & 0.97 & 215 & 0.334 \\
\hline & Private Sector & 161 & 69.21 & 15.27 & & & \\
\hline
\end{tabular}

Table 12. Kruskal-Wallis test to find out whether the level of job satisfaction (scores) of employees varies according to one-way analysis of variance $(\mathrm{N}=217)$

\begin{tabular}{|c|c|c|c|c|c|c|c|}
\hline \multirow{2}{*}{ Score } & \multirow{2}{*}{ Income } & \multicolumn{3}{|c|}{ Descriptive Statistic } & \multicolumn{2}{|c|}{ ANOVA } & \multirow{2}{*}{ Scheffe } \\
\hline & & $\mathbf{n}$ & $\bar{X}$ & ss & $\mathbf{F}$ & Sig. & \\
\hline \multirow{4}{*}{ Job Satisfaction } & $1500.00-3000.00$ TL (1) & 76 & 67.58 & 15.83 & 4.07 & $0.008 * * *$ & 1,2 ile 3,4 \\
\hline & $3001.00-4500.00$ TL (2) & 76 & 67.53 & 14.73 & & & \\
\hline & $4501.00-6000.00 \mathrm{TL}(3)$ & 34 & 74.76 & 13.35 & & & \\
\hline & More than $6000.00(4)$ & 31 & 75.45 & 13.80 & & & \\
\hline
\end{tabular}

$\overline{* *} p<.01$

It was found that the level of job satisfaction of the employees showed a significant difference according to the income variable that shows employees' monthly earnings in the current job (Table 12). Employees with monthly income between 1,500.00-3,000.00 TL and 3,001.00 -4,500.00 TL have lower job satisfaction levels than employees whose income is higher than 4,501.00-6,000.00 TL and more than 6,000.00 TL.

\section{RESULTS AND FINDINGS}

Individual and organizational factors are the main determinants of job satisfaction level, according to the findings of this research. As a result, when the job satisfaction levels of the employees were evaluated in this research, it was revealed that the job satisfaction levels, in general, were moderate, not showing extremes on either end of the satisfaction scale.

In addition, the educational status of the employees, the number of jobs changes they made, the duration of employment at the current job, and the sector they are working do not cause a significant difference in their job satisfaction scores.

By the way, the study revealed that the level of job satisfaction of female employees is significantly higher than male employees. The level of job satisfaction among workers in the 45-54 age group is significantly higher than the 15-24 and 25-34 age group. The study shows that the level of job satisfaction of married employees is significantly higher than single employees. Employees who have been working for 15 years or more are found to have significantly higher job satisfaction levels than employees who have been working for 1-5 years. It is seen that the level of job satisfaction of employees whose income is higher than 4,501.00-6,000.00 TL and 6,000.00 TL is significantly higher than employees whose income is 1,500.00-3,000.00 TL and 3,001.00-4,500.00 TL.

Finally, the study suggests that individuals as well as organizations have obligations for job satisfaction. Individual accomplishments have a positive impact on the organizational success. For this reason, in addition to providing all the factors necessary to fulfill employees' job satisfaction, during the recruitment process, organizations should hire people who meet the qualifications required by the position, implement training and development processes, and also generate career plans that empower job satisfaction of employees. When individuals work on their career plan, they should choose the right job for their competencies in order to maintain a productive, happy and, a healthy working life.

\section{REFERENCES}

Asik, N. (2010). Çalışanların İş Doyumunu Etkileyen Bireysel ve Örgütsel Faktörler İle Sonuçlarına İlişkin Bir Değerlendirme [An Evaluation of Individual and Organizational Factors Affecting Employee Job Satisfaction and Their Results]. Türk İdare Dergisi - Turkish Administrative Journal, 467, 31-51.

Aslan, H. (2006). Çalışanların İş Doyumu Düzeylerine Göre Depresyon, Benlik Saygisl ve Denetim Odağl Algisı Değişkenlerinin İncelenmesi [Analysis of Depression, SelfEsteem and Locus of Control Perception Variables According to Employee Job Satisfaction Levels] (Unpublished Masters Thesis), Ankara University, Institude of Social Sciences, Ankara, Turkey.

Ataklı, A., Dikmentas E. and Altınisik, S. (2004). Üniversite Hastanelerinde Çalışan Yönetici ve Klinik Sekreterlerinin İş Doyumu [Job Satisfaction of Managers and Clinical Secretaries Working in University Hospitals]. Hacettepe Sağllk İdaresi Dergisi - Hacettepe Health Administration Magazine, 6(2), 157-166.

Aydin, S. (2019). Factors Affecting Patient Satisfaction With Healthcare System of Turkey (Doctoral Dissertations), University of South Carolina.

Eginli, A. (2009). Çalışanlarda İş Doyumu: Kamu Ve Özel Sektör Çalışanlarının İş Doyumuna Yönelik Bir Araştırma [Job Satisfaction in Employees: A Research on Job Satisfaction of Public and Private Employees]. Atatürk Üniversitesi İktisadi ve İdari Bilimler Dergisi - Ataturk University Journal of Economics and Administrative Sciences, 23(3), 35-52. 
Ergenc, A. (1982). İş Doyumunun Belirleyicileri Olarak Beklenti, Algılama Tutarsızlığı ve Çalışma Değerleri [Expectations, Perception Inconsistency and Working Values as Determinants of Job Satisfaction]. Management Psychology National Symposium (II, 16-19, 11-1991), Ankara: TODAIE Publications, pp. 309-340 (Türkiye ve Orta Doğu Amme İdaresi Enstitüsü Yayınları - Public Administration Institute for Turkey and the Middle East Publications, No: 201).

Glenn, N. D., Taylor, R. D. and Weaver, C. N. (1977). Age and Job Satisfaction Among Males and Females: A Multivariate Multi-Study. Journal of Applied Psychology, 62, 190-193. https://doi.org/10.1037/0021-9010.62.2.189

Groot, W. and Van Den Brink, H. M. (1999). Job Satisfaction Of Older Workers. International Journal of Manpower, 20(6), 344. https://doi.org/10.1108/01437729910289701

Kalaycı, S. (2006). SPSS Uygulamalı Çok Değişkenli İstatistik Teknikleri [SPSS Applied Multivariate Statistical Techniques] (2. Ed.). Ankara: Asil Publications.

Karagoz, Y. (2016). SPSS 23 ve AMOS 23 Uygulamal İstatistiksel Analizler [SPSS 23 and AMOS 23 Applied Statistical Analysis]. Ankara, Nobel Academic Publishing.
Kuzgun, Y., Sevim. A. S. and Hamamci, Z. (2005). Mesleki Doyum Ölçeğinin Geliştirilmesi [Development of Vocational Satisfaction Scale]. Rehberlik ve Psikolojik Danışmada Kullanılan Ölçme Araçları Dizisi - The Series of Measurement Tools Used in Guidance and Psychological Counseling, 1, 81-87.

Locke, E. A. (1976). The Nature and Causes of Job Satisfaction. In M. D. Dunnette (Eds.), Handbook of Industrial and Organizational Psychology (pp. 1297-1343). Chicago, IL: Rand McNally.

Robbins, S. P. (2000). Managing Today. New Jersey: Prentice Hall.

Solmus, T. (2004). İş Yaşamında Duygular Ve Kişilerarası İlişkiler: Psikoloji Penceresinden İnsan Kaynakları Yönetimi [Emotions and Interpersonal Relations in Business Life: Human Resources Management through the Psychology Window]. Istanbul, Turkey: Beta Publishing.

Telman, N. and Unsal, P. (2004). Çalışan Memnuniyeti [Employee Satisfaction]. Istanbul, Turkey: Epsilon Publishing.

Vroom, V. H. (1964). Work and Motivation. New York, USA: John Wiley \& Sons. 